Herasymenko O. S., Shapovalov V. Y., Yenin R. V., Koshikov M. A., Haida Y. I., Herasymenko S. D., Muradyan K. R., Okolets A. V. Optimization of diagnostics of combat injuries of the abdomen. Journal of Education, Health and Sport. 2021;11(04): 28-36. eISSN 23918306. DOI http://dx.doi.org/10.12775/JEHS.2021.11.04.003

https://apcz.umk.pl/czasopisma/index.php/JEHS/article/view/JEHS.2021.11.04.003

https://zenodo.org/record/4685065

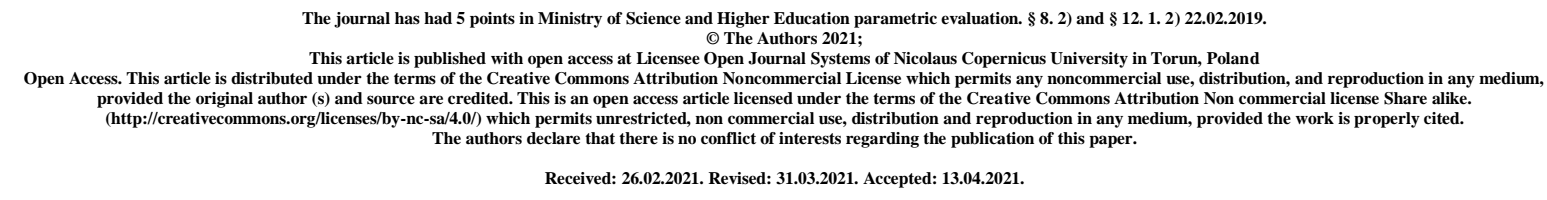

Received: 26.02.2021. Revised: 31.03.2021. Accepted: 13.04.2021.

\title{
OPTIMIZATION OF DIAGNOSTICS OF COMBAT INJURIES OF THE ABDOMEN
}

\author{
O. S. Herasymenko ${ }^{1,2}$, V. Y. Shapovalov ${ }^{1,2}$, R. V. Yenin ${ }^{1,2}$, M. A. Koshikov ${ }^{1}$, \\ Y. I. Haida' ${ }^{1}$, S. D. Herasymenko ${ }^{3}$, K. R. Muradyan ${ }^{1,2}$, A. V. Okolets ${ }^{1}$
}

\author{
${ }^{1}$ Military Medical Clinical Center of the Southern Region, Odessa, Ukraine \\ ${ }^{2}$ Odessa National Medical University, Odessa, Ukraine \\ ${ }^{3}$ Ukrainian Medical Dental Academy, Poltava, Ukraine
}

\begin{abstract}
The aim - to optimize the diagnostic scheme for combat abdominal injuries at the II level of medical care by identifying the most informative and fast instrumental diagnostic methods.

A clinical and statistical analysis of the results of surgical treatment of 496 wounded with combat abdominal injuries treated in military mobile hospitals from June 2014 to August 2017 was carried out. Additional diagnostic tests were conducted for the injured with BPH in the comparison groups - FAST protocol, laparocentesis and diagnostic laparoscopy.

In the general array of the study $(n=496)$, the FAST protocol was performed by 208 wounded (41.9\%), laparocentesis - 270 (54.4\%), video laparoscopy - 103 (20.8\%). The number of emergency ultrasound studies in the volume of the FAST protocol with combat abdominal injuries in group 1 was $19.2 \%$, in group $2-40.7 \%$, in group $3-66.5 \%$. A more frequent FAST protocol for injured with BPG at level II of medical care in groups 2 and 3 resulted in a decrease in the number of laparocentesis performed from $68.3 \%$ (in group 1) to $38.6 \%$ (in group 3), and an
\end{abstract}


increase in the number of video laparoscopic studies from $14.9 \%$ (in group 1) to $26.6 \%$ (in group 3), most of which turned into therapeutic laparoscopy.

The data obtained indicate that the widespread introduction of the FAST protocol into the PID diagnosis scheme at the II level of medical care helps to reduce the number of invasive (often unfounded) methods, namely, laparocentesis and diagnostic laparotomy, reduce the time spent on diagnosis and the choice of optimal surgical tactics.

Key words: combat injuries of the abdomen; laparocentesis; videolaparoscopy; ultrasound.

Анотація. Метою роботи є оптимізація схеми діагностики бойових ушкоджень живота на II рівні медичної допомоги шляхом виділення інформативних та швидких інструментальних діагностичних методів.

Проведено клініко-статистичний аналіз результатів хірургічного лікування 496 поранених з бойовими пошкодженнями живота, які проходили лікування в військових мобільних госпіталях в період з червня 2014p. по серпень 2017p. Пораненим проводились додаткові діагностичні дослідження - FAST-протокол, лапароцентез та діагностична лапароскопія.

В загальному масиві дослідження $(\mathrm{n}=496)$ FAST-протокол був виконаний 208 пораненим (41,9\%), лапароцентез - 270 (54,4\%), відеолапароскопія - 103 (20,8\%). Кількість екстрених ультразвукових досліджень в об'ємі FAST-протоколу в групі 1 склала 19,2\%, в групі 2 - 40,7\%, в групі 3 - 66,5\%. Більш часте проведення FAST-протоколу пораненим з БПЖ на II рівні медичної допомоги в групах 2 та 3 призвело до зниження кількості виконаних лапароцентезів з 68,3\% (в групі 1) до 38,6\% (в групі 3), та збільшенню кількості відеолапароскопічних досліджень з 14,9\% (в групі 1) до 26,6\% (в групі 3), більшість з яких перетворилася на лікувальну лапароскопію.

Отримані дані вказують на те, що широке впровадження FAST-протоколу в схему діагностики БПЖ на II рівні медичної допомоги сприяють зменшенню кількості інвазивних (нерідко необгрунтованих) методів, а саме лапароцентезів та діагностичних лапаротомій, скорочують затрати часу на постановку діагнозу та вибір оптимальної хірургічної тактики. 


\section{Ключові слова: бойові пошкодження живота; лапароцентез;}

відеолапароскопія; ультразвукове дослідження.

Аннотация. Целью работы является оптимизация схемы диагностики боевых повреждений живота на II уровне медицинской помощи путем выделения информативных и быстрых инструментальных диагностических методов.

Проведено клинико-статистический анализ результатов хирургического лечения 496 раненых с боевыми повреждениями живота, проходивших лечение в военных мобильных госпиталях в период с июня 2014 по август 2017г. Раненым проводились дополнительные диагностические исследования - FAST протокол, лапароцентез и диагностическая лапароскопия.

В общем массиве исследования $(\mathrm{n}=496)$ FAST протокол был выполнен 208 раненым (41,9\%), лапароцентез - 270 (54,4\%), видеолапароскопия - 103 (20,8\%). Количество экстренных ультразвуковых исследований в объеме FAST-протокола в группе 1 составила 19,2\%, в группе 2 - 40,7\%, в группе 3 - 66,5\%. Более частое проведение FASTпротокола раненым с БПЖ на II уровне медицинской помощи в группах 2 и 3 привело к снижению количества выполненных лапароцентез с 68,3\% (в группе 1) до 38,6\% (в группе 3), и увеличению количества видеолапароскопичних исследований с 14,9\% (в группе 1) до 26,6\% (в группе 3), большинство из которых превратилась в лечебную лапароскопию.

Полученные данные указывают на то, что широкое внедрение FAST-протокола в схему диагностики БПЖ на II уровне медицинской помощи способствуют уменьшению количества инвазивных (нередко необоснованных) методов, а именно лапароцентез и диагностических лапаротомий, сокращают затраты времени на постановку диагноза и выбор оптимальной хирургической тактики.

Ключевые слова: боевые повреждения живота; лапароцентез; видеолапароскопия; ультразвуковое исследование.

Introduction. In the conditions of modern military operations the specific weight of abdominal wounds in the general structure of combat injuries fluctuates from $6,6 \%$ to $9 \%$, according to anti-terrorist operation makes 4-7\%. The relationship between the results of 
treatment of abdominal injuries with the timing and quality of surgical care, with the timing and type of medical evacuation from different levels of medical care, creates great organizational difficulties, especially with the mass influx of wounded. Specific features of gunshot wounds of the abdomen cause a greater severity of functional disorders, more frequent development of complications (54-81\%) and, as a consequence, a higher mortality rate (12-31\%) than with injuries of other localizations. Wounded in the abdomen are subject to staged surgical treatment at the II-IV levels of medical care. Of particular importance in saving the lives of the wounded in the abdomen is the second level of medical care (stage of qualified surgical care), where stabilizing surgeries and anti-shock measures are carried out, after which the wounded are evacuated to the next level. The diagnostic phase at this stage plays a crucial role in decisionmaking and choice of surgical tactics, so the optimization of the diagnostic process at the second level of medical care in combat is relevant.

The purpose of the work. To optimize the scheme of diagnosis of combat injuries of the abdomen at the II level of medical care in the conditions of armed conflict by selecting the most informative and fast instrumental diagnostic methods.

Materials and methods. A clinical and statistical analysis of the results of surgical treatment of 496 wounded with combat injuries of the abdomen, who were treated in military mobile hospitals in the period from June 2014. to August 2017 There are 3 comparison groups: group 1 - wounded who were treated in the period from June 12, 2014 to August 31, 2015 (control group); group 2 - wounded who underwent treatment in the period from September 1, 2015 to August 31, 2016 (experimental group 1); group 3 - wounded who underwent treatment in the period from September 1, 2016 to August 31, 2017 (experimental group 2). Group 1 included 161 wounded with an average age of $32.3 \pm 2.5$ years; in group 2 - 177 wounded with an average age of $34.1 \pm 2.3$ years; in group $3-158$ wounded with an average age of $33.2 \pm 2.4$ years. All the wounded were men. In group 1, gunshot wounds to the abdomen (HRV) were observed in 137 people (7.1\%), closed abdominal injuries (CL) - in 24 people (1.2\%). The share of BPZ among the lesions of all localizations was $8.4 \%$. In group 2, 152 people were injured, which was $6.18 \%$ of the wounds of all localizations, 25 - 1.02\%. In group 3, HPV was observed in 143 people (5.16\% of all injuries), HF - in 15 (0.54\%). In general, in all comparison groups, HPV accounted for 432 cases (6.03\% of injuries in all localizations), HRT - 64 cases $(0.89 \%)$, BPH in total - 496 people, which was $6.92 \%$ among combat injuries of all localizations. 
Additional diagnostic tests, namely FAST protocol, laparocentesis and diagnostic laparoscopy, were performed in the comparison groups according to the availability of appropriate equipment for the wounded with BPH.

FAST protocol (Focused Assessment Sonography for Trauma) is a limited ultrasound examination aimed exclusively at detecting "free fluid" in the peritoneal cavity, pleural cavity and pericardial sac, as well as determining the presence of pneumothorax.

We started using the FAST protocol at the second level of medical care from the first days of operation of the 61st VMG in the field, but this study was conducted sporadically in the presence of a specialist.

Subsequently (2015-2016), after changing the location of the field hospital, FASTprotocol was performed more often (during this period, the hospital staff was introduced ultrasound), but not all the wounded. In the period of 2016-2017, the entire medical staff of the mobile hospital was trained by specialists of the Ukrainian Military Medical Academy in the methods of conducting the FAST protocol. During this period, the study was conducted on all wounded, regardless of the location of the injury. This technique was used not only in the city of the hospital, but also when examining the wounded on the road, including mass receipts.

After evaluating the results of the FAST protocol, some of the wounded according to the indications performed laparocentesis by the method of "wandering catheter".

Videolaparoscopic operations (VLO) for combat abdominal injuries in the field began to perform in group 1 in July 2014 (for the first time in Ukraine). Indications for VLO were considered to be uncertainty in the penetrating nature of the wound (for differential diagnosis), questionable results of laparocentesis, stability of hemodynamic parameters of the wounded and medical and tactical factors (lack of mass admission of the wounded).

Results and discussion. With penetrating gunshot wounds in group 1, 3 wounded out of 12 were examined, the most often positive result was observed in zone 6 ( 2 cases), less often in zones 1 and 4, and 5 ( 1 case each). With penetrating shrapnel wounds, 18 wounded out of 82 were examined, a positive result was most often observed in zone 6 (14 cases), then in descending order in zones 4 (4 cases), 5 (3 cases), 1 ( 2 cases), 2 and 7 (1 case). In nonpenetrating bullet wounds, fluid was detected in one wounded in zones 1.5 and 6 (with rupture of the liver due to a side impact). With non-penetrating shrapnel wounds in zone 5 (2 cases) and one case in zones 4, 6 and 7. With closed combat injuries of the abdomen in group 1 in the wounded 
with injuries OCHP most often found fluid in zones 6 and 5 (respectively 3 and 2 cases), less often in zones 1 and 3 ( 1 case each). In the wounded without injuries OCHP positive test result was obtained in 1 case in zone 7 due to extra-abdominal injury.

In penetrating gunshot wounds in group 2, the most common positive result of the FAST protocol occurred in zone 6 ( 5 cases), in zone 5 ( 3 cases), then in descending order in zone 1 ( 2 cases) and 8 (1 case). With penetrating shrapnel wounds - most often in zone 6 (24 cases), then in descending order in zones 5 (18 cases), 1 (12 cases), 4 (6 cases), 7 (3 cases), 8 (2 cases) and 2 (1 case). In non-penetrating bullets, a positive result of the FAST protocol was in one wounded in zones 1, 5 and 6. In non-penetrating shrapnel wounds, a positive result of the FAST protocol was observed in zone 8 (3 cases), and in zone 7 in one case of extra-abdominal injuries. In case of STDs in group 2, the most frequently positive result of the FAST protocol was observed in zones 6 and 5 (cases 4 and 2, respectively) and in one case in zone 4. In the wounded without injuries, the incidence was observed in zone 8 in one wounded.

In penetrating gunshot wounds in group 3, the most often positive result was found in zone 6 ( 8 cases), in zones 4 and 5 (3 cases each), in zone 1 ( 2 cases), least often in zone 8 (1 case). With penetrating shrapnel wounds - most often in zone 6 (49 cases), then in descending order in zone 5 (17 cases), 4 (12 cases), 1 and 7 (7 cases each), 3 (6 cases), 8 (5 cases). With nonpenetrating bullet wounds, a positive result was detected in zone 6 in 1 case. With nonpenetrating shrapnel wounds in zones 8 (2 cases) and 5, 6, 7 (1 case each). At ZBTZh in group 3 at wounded with OCP injuries the positive result in zones 6, 5, 1, 4 (accordingly 8, 6, 5 and 4 cases), less often in zones 2 and 8 (on 1 case) was most often defined. In the wounded without injuries, a positive result was observed in zone 2 in 1 case.

After evaluating the results of the FAST protocol, some of the wounded according to the indications performed laparocentesis by the method of "wandering catheter".

In group 1, with penetrating gunshot wounds, laparocentesis was performed on 76 out of 94 wounded ( 8 wounded with bullet wounds, 68 - with shrapnel wounds), which amounted to 80.9\%. A positive result was observed in the 51st wounded (67.1\%), doubtful - in $11(14.5 \%)$, negative - in 14 (18.4\%), not performed - in 18 cases (19.1\%). In the wounded with closed combat injuries of the abdomen with injuries of internal organs in the first group laparocentesis was performed on 10 wounded out of 12 , which amounted to $83.3 \%$. A positive result was observed in 6 wounded (60\%), doubtful - in $3(30 \%)$, negative - in the 1st (10\%). In the subgroup 
of wounded without damage to the abdominal organs laparocentesis was performed in 4 cases out of $12(33.3 \%)$. In 3 cases there was a negative result, in the 1 st - doubtful.

At penetrating gunshot wounds of a stomach in group 2 laparocentesis was carried out at 59 wounded from $81(72,8 \%)$, namely - at bullet wounds at 11 from 18, at shrapnel - at 48 with 63-oh. With penetrating bullet wounds, a positive result was observed in 7 cases (63.6\%), doubtful in $2(18.2 \%)$, negative - in $2(18.2 \%)$. At penetrating shrapnel wounds of a stomach the positive result was in 27 cases $(50,9 \%)$, doubtful in $17(32,1 \%)$, negative in $4(7,5 \%)$. In nonpenetrating bullet and shrapnel wounds of the abdomen in group 2, laparocentesis was performed on the $2^{\text {nd }}$ and $4^{\text {th }}$ wounded, respectively, in all cases the result was negative. At ZBTZh in group 2 laparocentesis was carried out by 11 wounded from 25 (44\%). In the wounded with OCP injuries in 6 cases there were positive results, in 2 - doubtful. In the wounded without damage to the PPP in 3 cases there was a negative result.

At penetrating gunshot wounds of the abdomen in group 3 laparocentesis was performed in the 42nd wounded out of 97 (43.3\%), namely - with bullet wounds in 8 out of 14, with shrapnel wounds - in 34 out of 83-oh. When penetrating bullet wounds.

In group 2, with penetrating bullet wounds of the abdomen, the diagnostic drug was performed by the 3rd wounded, medical - 5, in all cases, the diagnostic drug underwent laparotomy. At penetrating shrapnel wounds 15 VLO (in 13 cases - medical drugs, in 2 diagnostic, which in the 1st wounded ended in conversion, and in one case there was a penetrating shrapnel wound without damage to internal organs (the shrapnel damaged the peritoneum), most of it was in the anterior abdominal wall, less - in the abdominal cavity.) In non-penetrating gunshot wounds in 5 cases performed diagnostic drugs (1 - in bullet, 4 - in shrapnel). Videolaparoscopy for STDs in group 2 was performed 9 -in wounded out of 25, 7 wounded were found to have abdominal injuries.In 2 cases of diagnostic drugs had to resort to conversion laparotomy.In the 1st case was found a small extraperitoneal hematoma that did not require surgical treatment, in two - no injuries were detected, so the scope of operations was limited to diagnostic drugs.In 4 cases, laparoscopy was curative.

In group 3, with penetrating bullet wounds of the abdomen, the diagnostic drug was performed on the 1st wounded (who underwent a conversion laparotomy), medical - 5. At penetrating shrapnel wounds 17 VLO (in 14 cases - medical drugs, in 3 - diagnostic, which in all 3 wounded ended in conversion. At non-penetrating bullet gunshot wounds of a stomach in 2 
cases diagnostic drugs were performed). in one case we had to resort to a conversion laparotomy for damage to the cecum and ascending colon due to hydrodynamic impact.) In impenetrable shrapnel wounds, diagnostic laproscopy was performed on 9 wounded.Videolaparoscopy for STD in group 3 was performed In 6 cases of diagnostic laparoscopy, conversion laparotomy had to be performed. In two cases, the scope of the operation was limited to diagnostic drugs, in the 1st case hematoma of the large omentum was found, in one - subcapsular hematoma of the spleen, which did not require surgical treatment. In one case, no damage was detected. In 4 cases, laparoscopy was curative.

Thus, in the total study array $(\mathrm{n}=496)$ FAST-protocol was performed on 208 wounded (41.9\%), laparocentesis - 270 (54.4\%), videolaparoscopy - 103 (20.8\%).

The number of emergency ultrasound examinations in the volume of the FAST protocol for combat injuries of the abdomen in group 1 was $19.2 \%$, in group $2-40.7 \%$, in group 3 $66.5 \%$. More frequent FAST protocol for patients with BPH at the II level of medical care in groups 2 and 3 led to a decrease in the number of performed laparocentesis from $68.3 \%$ (in group 1) to $38.6 \%$ (in group 3), and an increase in the number of videolaparoscopic studies from $14.9 \%$ (in group 1) to $26.6 \%$ (in group 3), most of which turned into medical laparoscopy.

Conclusions. The obtained data indicate that the widespread introduction of FASTprotocol in the scheme of diagnosis of combat injuries of the abdomen at the II level of medical support helps to reduce the number of invasive (often unreasonable) methods, namely laparocentesis and diagnostic laparotomies, reduce the time spent on diagnosis and choice of surgery tactics.

\section{References}

1. E.V. Svitlychnyi, O.I. Hrechanyk. Ultrazvukova diahnostyka travmy ta yii uskladnen. K.: SPD Chaplynska N.V., 2016. - 215 s. (in Ukrainian).

2. I.P. Khomenko, E.V. Svitlychnyi, O.I. Hrechanyk, O.M. Melnyk, B.A. Tarasiuk, K.R. Muradian. Ekstreni ultrazvukovi doslidzhennia pry travmi FAST-protokol. - Kyiv: «Vydavnytstvo Liudmyla», 2018. - 66 s. (in Ukrainian).

3. Chestovich PJ, Browder TD, Morrissey SL, Fraser DR, Ingalls NK, Fildes JJ. Minimally invasive is maximally effective: diagnostic and therapeutic laparoscopy for 
penetrating abdominal injuries. J Trauma Acute Care Surg. 2015;78: 1076-1085. doi: 10.1097/TA.0000000000000655.

4. Como JJ, Bokhari F, Chiu WC, Duane TM, Holevar MR, Tandoh MA, et al. Practice management guidelines for selective nonoperative management of penetrating abdominal trauma. J Trauma. 2010;68: 721-733. doi: 10.1097/TA.0b013e3181cf7d07

5. Koto MZ, Matsevych OY, Motilall SR. The role of laparoscopy in penetrating abdominal trauma: our initial experience. J Laparoendosc Adv Surg Tech A. 2015;25: 730-736. doi: 10.1089/lap.2015.0042.

6. Lee PC, Lo C, Wu JM, Lin KL, Lin HF, Ko WJ. Laparoscopy decreases the laparotomy rate in hemodynamically stable patients with blunt abdominal trauma. Surg Innov. 2014;21: 155165. doi: $10.1177 / 1553350612474496$

7. Lin HF, Chen YD, Lin KL, Wu MC, Wu CY, Chen SC. Laparoscopy decreases the laparotomy rate for hemodynamically stable patients with blunt hollow viscus and mesenteric injuries. Am J Surg. 2015;210: 326-333. doi: 10.1016/j.amjsurg.2014.11.009

8. Lin HF, Wu JM, Tu CC, Chen HA, Shih HC. Value of diagnostic and therapeutic laparoscopy for abdominal stab wounds. World J Surg. 2010;34: 1653-1662. doi: 10.1007/s00268-010-0485-5.

9. Nicolau AE. Is laparoscopy still needed in blunt abdominal trauma? Chirurgia (Bucur). 2011;106: 59-66.

10. Uranues S, Popa DE, Diaconescu B, Schrittwieser R. Laparoscopy in penetrating abdominal trauma. World J Surg. 2015;39: 1381-1388. doi: 10.1007/s00268-014-2904-5. 